\title{
MAPS, AND ONTOLOGIES BPM FOR MODELING AND ANALYSIS OF FLOW INFORMATION: laboratory journal
}

MAPAS, ONTOLOGIAS E BPM PARA MODELAGEM E ANÁLISE DO FLUXO DE INFORMAÇÃO: Jornal laboratório

MAPAS, ONTOLOGÍAS Y BPM PARA MODELADO Y ANÁLISIS DEL FLUJO DE INFORMACIÓN: Jornal Laboratório

\section{Benedito Medeiros Neto}

Post-Doctorate/Informatics: Semantic FrameWork for Journalism by CIC/IE/UnB (2018). Post-Doctorate: Digital Literacy and Mobile Learning by Escola de Comunicação e Arte/USP (2014). Professor FACIUnB and CIC\UnB. medeirosneto@unb.br

0000-0001-9562-1587

\section{Thallita Alves Silva}

Journalist from the University of Brasilia (UnB). Workflow to assist in the modeling of news production processes in laboratory newspapers. E-mail: thallitaessi@gmail.com

Received: 02.16.2021.

Accepted: 04.16.2021.

Published: 07.01.2021.

\section{ABSTRACT::}

This research shows modeling based on mental and conceptual maps the workflow of a university journal and proposes a

\begin{abstract}
domain ontology. The study was carried out based on concepts such as multiplatform journalism, web journalism and the use of ICT. In methodological terms, it is a case study, combined with participant observation through semi-structured interviews. It was developed, as a part of the modeling, a mind map of the Campus Multiplataforma workflow. Then the process was improved to a concept map and finally the study arrived at a ontology. The results show the possibility of visually understanding the process of a newspaper, sharing or extrapolating it and applying it to other newsrooms, and also improving the workflow with the support of the process management map (BPM).
\end{abstract}

KEYWORDS: Workflow; Journalism Multiplatform experimental-journal; Mental mapa and conceptual map; Ontology.

\section{Introduction}

The journalism that shares its raw material, information, through the use and mediation of technologies, is no exception, and should take advantage of the use of Information and Communication Technologies - ICT, notably algorithms, automation of the processes of collection, evaluation, composition, presentation and distribution of news. Therefore, the traditional means of communication of the last century, and even the most recent ones that emerged in the last two decades, seek to reorganize their business management models to remain in the market.

Information and Communication Technologies - ICT, propelling a revolution that continues in activity, which transforms, directly or indirectly, organizations and businesses in the main sectors of society, impacted fundamentals or obtained excellent results. This happens today in production processes in agriculture, industry, commerce, 
services and government. Journalism today still makes medium access to information from aggregators, social media and open data (BERVEN et al, 2020).

Professionals who deal with communication, news and information face challenges every day, whether the volume of data and information, whether the new forms of production or the adequacy of the treatment and distribution of news. They also understand that information and its distribution, if possible, in real time, are being created and thought of as to get closer to readers across the planet, and that this is more than a simple network connection. The sum of equipment in the data center allows for more big data in the cloud each month, and the more powerful the more accessible it is.

There is an increase in telecommunications networks, whether by fiber, or microwave, parallel to the profusion of applications (APP) for cell phones, and with the dynamic social networks, heavily impacted by the era of data and information, and data journalism. This expansion favors the necessary conditions for an environment of innovations and ruptures at different levels of the process of making journalism (DEUZE; WITSCHGE, 2018).

The consumption of information has undergone major changes with the advent of Internet 1, 2 and 3, and the evolution of new digital technologies, such as ICT applications, robots, and process automation. The access of the Brazilian population to the internet already reaches 134 million users, according to the TIC Household Survey 2019, (Cetic.br), connected to the Internet Steering Committee in Brazil and represents $74 \%$ of the population aged 10 or over. Therefore, to plan and organize the production of content, it is necessary to make use of unconventional procedures and tools, which Internet 3.0 incorporates into Semantic Web technologies.

Communication formats and content consumption have been transformed by new technologies. In this scenario, journalism has been impacted and its processes rethought given the strong presence of technologies and the emergence of new communication channels. There is also the need to adapt the language of professionals to keep up with demands and occupy spaces for information and interaction with the public. The presence of journalistic venues are expanding, as are useful working tools. Production processes can rely on ICTs, for example, e. g., the process his research we here deal with, which presents a design of the workflow of the production of a newspaper: Campus Online (BARCELLOS; SILVA, 2019).

In a planning stage of the processes of content production in newsrooms of national and international newspapers, it is necessary to study and identify the technologies to support the teams, starting with the design of the workflow (productive routines) of the newsroom and the definition of IT tools as support. The implementation 
of collaborative systems, the presence on social networks, computer supportted collaborative learning, information standards, digital media management models and improvement of the CMS - Content Management System should also be part of the convergent writing scope (JORGE et al, 2016 ).

In this context of transformation that most organizations that are not just journalistic undergo, two points stand out. The first is that digital convergence is gaining momentum. Therefore, it is necessary to think of new ways to improve the performance of journalistic work. A way of preparing for this converging journalism scenario, the virtual newsroom and multimedia production environments are the teaching chains, represented by the journal-labs, which play a crucial role in the professional construction and approximation of students with the reality of the market of work (JORGE et al, 2016).

The second point has to do with the unquestionable digital transformation that all organizations undergo. Managers are permanently required to present new management and business models, based on innovation as it is considered that the current models in force cannot respond to market challenges. while organizational practices within newsrooms and in relations with the customers, media companies and their consumers are not flexible enough. And, therefore, they are not appropriate for the reality in which media companies currently operate and explore (SANTOS et al, 2019).

Given this context, this research proposes to describe the context and study the case of the laboratory-newspaper Campus Multiplataforma ${ }^{1}$;. This involves workflow mapping and the construction of an ontology for the modeling and analysis of processes, the documentation and technological implementations that lead to the continuity and improvement of innovation research for the teaching and practice of journalism in universities and, in the future, in companies in the sector (FONSECA et al, 2018)

The objectives of this research can be summarized as:

a) Develop mental maps and conceptual maps of the production process of the Campus Multiplataforma laboratory-newspaper

b) Build the Campus Multiplataforma workflow ${ }^{2}$ based on ontology;

c) Analyze the model of the process, production, and the synergy of journalism for its understanding and improvement.

\footnotetext{
1 http://app.campus.fac.unb.br: The online version of the Campus Multiplataforma newspaper was created in 2007 and of a discipline in the 5th semester of the Journalism course at UnB. With a multiplatform journalism, Campus Online shares information about everything that happens at the Universidade de de Brasília.

2 SILVA, T. A. Workflow to assist in the modeling of news production processes in laboratory newspapers. TCC presented to the Faculty of Communication of the Universidade de Brasília, Brasília, DF. 2019
} 


\section{Semantic Web and a case study and observation of the Multiplatform Campus}

Although journalists themselves recognize that they can often be quite resistant to change, and the implementation of information technologies, such as applications (APP) and information systems, this has always been something they have been concerned about. But at the same time, this picture or situation can indicate a general feeling of optimism when professionals are encouraged to get involved with new technologies and new formats, which requires a new posture from the managers of newsrooms and members of each editorial (SANTOS et al., 2019).

The fact is that all newspapers in South and Central Americas have been looking for viable business models and the adoption of efficient workflows for their newsrooms, since the revenue from digital products and services is not enough to support the operating costs of a newspaper company, which currently operates with a 1:10 ratio. Even with the facilities that new technologies offer (which become more accessible every day), the content production for data journalism, text journalism and audio and video journalism is still expensive (JORGE; MEDEIROS NETO, 2021).

In this unfavorable scenario for journalistic organizations, the technological impact and the need to adapt journalists to work fully inserted in cyberspace must be considered, therefore, it is essential to follow the new directions for the Web in this decade. In this sense, we see the concept and application of the Semantic Web (3.0), which is directly linked to the format of content on the Web and the type of material that must be produced for the online environment, and for the use of procedures based on its technologies (BERNERS-LEE; HENDLER; LASSILA, 2001).

The Semantic Web concept emerged in an article published in Scientific American which was authored by Tim Berners-Lee, James Hendler and Ora Lassila (EBERTZ, 2013). "the name given to the 2001 article, which paved the way for new reflections and contributions to the concept.was The semantic Web: a new form of Web content that is meaningful to computers, will unleash the revolution of new possibilities.

The current Web or Syntactic Web (BREITMAN, 2005) is developed in natural language, following the orientation of our mother tongue. It is made up of hypertexts, which the computer does not interpret, it just presents to users. While the Semantic Web is composed of tools and agents, the Web Services, presents semantic models, metadata, ontologies and structured language appropriate to the Web.

The use of Content Ontologies and the Semantic Web in journalism by journalists is already a reality today. In fact, even before attempts to use semantic technologies, 
newspapers had already made significant investments in their news management systems and undertaken considerable standardization efforts to facilitate interoperability (TRONCY, 2008). From an early stage, the research explored a semantic orientation in journalistic production (e.g., the use of metalanguage, ontology and Semantic Web technologies) and how they can support the development of collaborative systems that support production functions within journalistic writing (MEDEIROS NETO et al 2019).

One of the main differences we can notice from Web 2.0 to 3.0 is in search times, since concepts not being structured and correlated generates a very large number of results and, in many with issues out of context due to Low precision. The Semantic Web offers technical resources that make publishing and retrieval actions on new Internet channels simple. And the use of smarter and more pragmatic Content Management Systems (CMS) brings "possibilities of identifying meanings and generating inferences and have the potential to maximize automation in the processes performed by machines" (LEL; MIELNICZUK, 2012).

Based on the concepts seen and facilities already available, the Semantic Web enables a greater organization of information on the network, allows the content made available on portals to be understood and interpreted by computers (BREITMAN, 2005) and this can mean more content connections, results in more accurate search and time saving for shared work environments such as virtual newsrooms.

Tim Berners-Lee (2001) suggested a layered model for structuring the web of the future that was popularized as the "wedding cake". This model is organized in a layered construction, which evolves with each step. The proposal can be seen in Figure 1, as one of the views of the Semantic Web by the W3C Consortium (World Wide Web Consortium).

Among the diversity of elements that make up the Semantic Web is the ontology, which is the conceptualization of terms: the elaboration of a vocabulary specific to an area of knowledge. In this work, ontologies are fundamental for the construction of vocabularies specific to an newsroom, which can be used in semantic annotations, accessed and processed automatically (PATEL-SCHNEIDER, 2001 apud CHAVES, 2015, p. 47).

Ontologies, content and Semantic Web are subjects that have been working together for a long time. From an early stage, the research explored a semantic orientation in journalistic production (e.g., the use of metalanguage, ontology and Semantic Web technologies) and how they can support the development of collaborative systems that assist production functions within journalistic writing and distribution through communication channels. 
In fact, even before the attempts to use semantic technologies, newspapers had already made significant investments in their news management systems (CMS), and had undertaken considerable standardization efforts to facilitate the interoperability of their contents (TRONCY, 2008).

Considering the structure of the Semantic Web and the methodology of this case study, data and information from the production process are gathered using direct observations, systematic interviews and in files available on the Campus Multiplataforma for this research.

In the case of the Campus Multiplataforma, the projects that portray the editorial line, proposals and decisions taken by the classes of the discipline "Campus Multimidia" of the Department of Journalism/FAC/UnB of 2017 and 2018 were analyzed. Also, to improve the understanding of the processes, some of the 1/2019 classes and interviews with decision-making students were observed (BARCELOS; GIL, 2018).

The understanding of the Campus and the collection of data and information relied on the qualitative empirical process, in which it was possible to: (a) identify the changes and adjustments implemented for each group of the laboratory-newspaper, (b) describe the changes, (c) map the relationship of students with the number of reporters and editors, and (d) identify platforms and narratives. This process enables, since the beginning of the research, a more detailed and in-depth understanding of the work in the Campus Multiplataforma journal (MOLINA: MEDEIROS NETO, 2017). For such an understanding, it was observed:

a) The Definition of work platforms;

b) The use of journalistic narratives;

c) Agenda discussion;

d) Task distribution;

e) Distribution on platforms;

f) Composition of working groups; and

g) Content repercussion analysis

The Campus workflow model presented here was built based on data collection and information available to students and on participant observation. Once the mental map $^{3}$ was developed as the basis for the beginning of the Campus workflow, interviews were carried out to validate the workflow (See Table 1).

\footnotetext{
${ }^{3}$ MENTAL MAPA is a thought organization technique that can be used to study, to plan a work or any other type of project:
} 
Table 1 - Use of Platforms on Campus

\begin{tabular}{|c|c|c|c|c|c|}
\hline Plataforms & $1 / 2017$ & $2 / 2017$ & $1 / 2018$ & $2 / 2018$ & $1 / 2019$ \\
\hline Aps & No & No & Development & Yes & Yes \\
\hline Facebook & Yes & Yes & Yes & Yes & Yes \\
\hline Instagram & Yes & Yes & Yes & Yes & Yes \\
\hline Site & Yes & Yes & Yes & Yes & Yes \\
\hline Twitter & Yes & Yes & Yes & Yes & Yes \\
\hline WhatsApp & No & No & No & Yes & Yes \\
\hline YouTube & $\begin{array}{c}\text { Yes } \\
\text { (repository) }\end{array}$ & Yes & Development & Stationary & Yes \\
\hline
\end{tabular}

Source: SILVA, 2019, p.57

The participant observation was carried out in the second semester of 2018 and in the first semester of 2019, in twelve classes of the Multimedia Campus discipline, with notes on: the main conversations of the class, student behavior, member commitment, participation and contribution to decision-making, monitoring the distribution of the agenda by reporters and definitions of the deadline for delivery. By observing the production of the laboratory-newspaper, it was structured in a framework with digital and editorial presence in different platforms throughout the analyzed semesters (SILVA, 2019).

Once the acting platforms were understood, the next step was to understand the composition of the newspaper's actors (See Figure 2).

And from these two scenarios, this study began the elaboration of the workflow in the form of a mental map, which was improved to a conceptual map ${ }^{4}$ and evolved to an ontology, as will be presented in the next item.

http://www.filosofiacienciaarte.org/attachments/article/992/Mapa\%20MENTAL\%20V4- 3\%20\%202016-1718-2019.pdf.

${ }^{4}$ CONCEPTUAL MAPS are graphical tools (diagrams indicating relationships between concepts/words) for organizing and representing knowledge. They should not be confused with organization charts or flow 


\section{Campus Processes and Workflow}

In the first decade of this century, existing news workflow processes were little seen as workflow. In the opinion of TRONCY (2008) news items are typically: i) produced by news agencies, independent journalists, or citizen media; ii) its contents are improved by newspapers, magazines or broadcasters and iii) delivered to end users through the respective channels. News items usually when accompanied by a set of metadata ${ }^{5}$ and descriptions facilitate their storage and retrieval.

Nonetheless, in the beginning, much of the metadata was lost due to environment interoperability issues, which occur throughout the workflow, something that is changing with the use of big data and Semantic Web technologies, including in Brazil. Howevwe, in the end-user interface, opportunities to make use of the available metadata are often still missed. Consequently, readers and users are forced to explore news information in environments that contain large amounts of irrelevant, unreliable and repeated information. Moreover, nowadays with the presence of fake news, which adds to insufficient access to prior knowledge (TRONCY, 2008).

The representation of the production processes and workflow of the Campus newspaper included reading and direct observation during the discipline Campus Multimedia (2018 and 2019). And the use of best practices and technologies to represent the workflow was achieved using two tools: mind map and concept map, which are detailed below.

The discipline Campus Multimídia, from the journalism course at the Faculty of Communication at UnB, analyzes the impact of technological innovations on the transformation of journalism (the very invention of the movable type press, an emblematic landmark), which result in new presentation formats and/or in new platforms. Thus, in the first half of 2017, a collective work was inaugurated, built by students coordinated by a teacher (BARCELLOS; SILVA, 2020).

The development of the Project and collective development process of a multiplatform digital news vehicle, every semester, guide a didactic process of creating

diagrams, as they do not imply sequence, temporality or directionality. http://www.filosofiacienciaarte.org/index.php/comunicacao-informacao-computacao/1004-modulo-ixmapas-conceituais-2

${ }^{5}$ Metadata, or Metainformation, is data about other data. An item of a metadata can tell what that data is about, usually information intelligible to a computer. Metadata makes it easier to understand the relationships and usefulness of information in the data. Metadata is indispensable for communication between computers, but it can also be intelligible to humans. See Wikipedia, https://pt.wikipedia.org/wiki/Metadata 
a multiplatform journalistic vehicle, fully allocated on the web, having as platforms some channels among the so-called social networks, Twitter, Facebook, Instagram, Youtube, WhatsApp, a website and one application (app.campusunb.br), for preferential consumption by smartphone (BARCELLOS; GIL, 2018).

\subsection{The Campus Mind Map}

The mind map was used as a first way of visualizing and understanding the Campus workflow in search of an intuitive record of the process. According to Buzan (2016), the creator of the technique, mind maps are ways of recording information. They allow you to convey what is in the mind, organize your thoughts and expand your understanding.

Over the two and a half years of work, there were several changes and adaptations specific to each class. The main contributions were: inclusion of new platforms, such as the Campus Application (DE SOUSA; BARCELLOS, 2019), WhatsApp, YouTube; inclusion of narratives, e.g. podcast, accessibility texts; and other changes with a more managerial characteristic, such as the distribution of reporters according to the demands of the agenda and not just by platforms (SILVA, 2019).

Considering the flexibility of the team, processes, editorial line and processes, a workflow was created to demonstrate the production steps of the Campus Multiplataforma composition. See APPENDIX 3: Figure 3 - Mind map in chronological view. Source: SILVA, 2019, p.69.

The mental map in Figure 3 (APPENDIX 3) was presented to the Editorial Board of the Multimedia Campus and validated, in 2019. Next, we will have the Concept Map and the Campus Ontology created based on the discipline's projects, class observation and face-to-face validation of the mental map (SILVA, 2019).

The identification of the Editorial Board, or at least one of the members, can be seen by the orange diamond throughout the process. The representation of the platforms has also the same format to mark that they all have the same relevance and do not exercise hierarchy or subordination to each other (BARCELLOS; SILVA, 2020).

For the design, we considered the journalism pre-agenda process mostly implemented by Radioescuta, which, this semester, was carried out by the editors themselves and presented to the Editorial Board for discussion and decision on whether to continue the agenda.

With the approval by the Editorial Board, the agendas will be directed to the appropriate platforms, with journalistic narratives and reporters already defined. In the investigation phase, interviews, capturing of images, videos and content for the 
construction of the article will be concluded. Then, the article moves to the review stage under the responsibility of the editor-in-chief of each platform.

The art team is constantly present in defining the best formats and visual language for the circulation of content. The editor-in-chief of each platform, in partnership with the reporters, distributes the content as planned and each editor has the role of capturing the metrics and sharing the results with the entire team. The data collected is important for the Council's decision cycle, whether on publication schedules, narratives or platforms. This process can happen simultaneously, in a virtual environment, with different guidelines, for one or multiple platforms.

\subsection{From the Editorial Board to the Campus Concept Map}

With the Mind Map prepared, adjusted by the observations of the 1/2019 class of the Campus Multiplataforma and validated by the Editorial Board, the Conceptual Map can be built. For the elaboration of the Conceptual Map, we considered the teams, platforms, types of narrative used and the work processes of the newsroom.

The decision to make a Concept Map of the Campus workflow came from the understanding that this is a practical way to describe and convey the connections between the laboratory-newspaper teams and evolve towards the development of the Campus Ontology. According to Moreira and Buchweitz (1993), the conceptual map technique is flexible and can be used for different situations and purposes.

The Concept Map was developed in CmapTools software, a tool of the Institute for Human and Machine Cognition (IHMC) ${ }^{6}$ in Florida. The technological solution was created precisely to encourage knowledge, allow the representation of data through maps, establish connections and relate terms individually or collectively (SILVA, 2019). Considering the connection flexibility and the best organization through the conceptual map, we created the map represented in Figure 4. See the APPENDIX 4: Figure 4 - Conceptual Map of the Campus Multiplataforma. Source: SILVA, 2019, p.73.

\section{Modeling the Campus Multiplataforma Domain Ontology}

We live in a "hyper connected" context and with the strong presence of information and communication technologies - ICTs in almost all sectors of society, and journalists are expected to improve their skills in the use of tools, as well as their practices

\footnotetext{
6 The IHMC CmapTools software empowers users to construct, navigate, share and criticize knowledge models represented as concept maps. Vide http://www.filosofiacienciaarte.org/index.php/comunicacaoinformacao-computacao/992-modulo-iv-mapa-mental
} 
and work routines with the use or support of ICTs. They can use information systems, applications, and even intelligent agents and robots. This frees them from working in repetitive routines without the need for any direct supervision. In doing so, they move vulnerably in and out of large and small newsrooms and news organizations, trying to make a difference and survive in an extremely competitive market. To face this challenge, it is necessary to intensify their knowledge and skills in technology (DEUZE; WITSCHGE, 2018).

Within the diversity of technologies, possibilities and methods of approaching the Semantic Web or Internet 3.0, Ontologies stand out. They are already consolidated in Computer Science, and more recently, they are already present in Information Science and Communication in many countries in Europe, the Americas and Asia. Ontology is a term originating from philosophy, which is linked to "the branch of metaphysics that studies the types of things that exist in the world". The spelling is derived from the Greek ontos, being, and logos, word. Its origin refers to the word category, which concerns the classification of species and things (ALMEIDA, 2003 apud MORAIS; AMBROSIO, 2007, p. 2). According to LAMMEL and MIELNICZUK (2012):

Ontologies offer a logical model of relationships between concepts, as in a taxonomy, and, in addition, establish rules of relationships between these concepts, such as belonging, equality or distinction. Ontologies enable greater automation in data processing, as inferences give machines autonomy.

To continue the study of methods and procedures for modeling the production process, it is necessary to understand the concept of ontology, to develop the ontology ${ }^{7}$ of the Campus and elaborate a representation of the newspaper's workflow in a structured, organized and conceptualized way. It is also necessary to know the bases of ontology and its tools/software such as Protégé (FONSECA et al, 2018).

The development of the modeling of the Jornal Experimental's production flow, based on ontology, continued, firstly, with the representation of the workflow through its Mind Map. Afterwards, with the description of the classes, and with the relations

\footnotetext{
7 Ontologies offer a logical model of relationships between concepts, as in a taxonomy, and, in addition, They establish rules of relationships between these concepts, such as belonging, equality or distinction. Ontologies enable greater automation in data processing, as inferences give machines autonomy. See http://www.filosofiacienciaarte.org/index.php/curso-programacao-python/1005-modulo-ix-mapasconceituais-3
} 
between classes and improvement of the representation, the Conceptual Map was achieved. Thus, it was possible to categorize the classes, their properties and relationships in the domain of university writing, an mportant step in the construction of their ontology (ISHIKAWA; MEDEIROS NETO, 2019).

The modeling of the domain ontology of the Campus Multiplataforma began, in fact, after determining the roles of the actors within the experimental newsroom. Then, the ontology modeling was placed in Protégé according to the roles and tasks in the news production process represented in Figures 3 and 4.

The production of the ontology takes place through the following steps: class hierarchy, object hierarchy (predicates), class attributes and class individuals. The ontology class hierarchy is in accordance with Figure 4. Classes that do not associate are modeled as disjoint (e.g., person and material). Figure 5 represents the modeling of objects according to the tasks present in the process. To meet the semantic search in a more generalized way, we modeled the (reporters, the instance of Reporter class and editor and also the, instance of Editor-in-Chief class.

For the development of the ontologies, occuringf in almost a semester, the students of the discipline Special Topics in Communication 1: Ontology ${ }^{8}$ (online) which is offered at $\mathrm{FAC} / \mathrm{UnB}$. Students ${ }^{9}$ were invited to work in a project team to develop the Campus ontology as the final work of the discipline. For this they performed the following tasks:

- Study and bibliographic survey on Ontology;

- Identification of ontological concepts, such as: subject, predicate, object, classes, instances and class properties;

- Follow-up of tutorials about Protégér

- Creation of relational frameworks;

- Tool tests;

- Registration of identified classes;

- Insertion of predicates;

- Review of relationships between classes and predicates;

- Registration of objects;

- Insertion of instances; and

\footnotetext{
${ }^{8}$ ca The discipline TEC1: Ontology (online) at FAC/UnB aims to provide the complementation of knowledge in the area of computer science for social communication, enabling the updating and deepening of topics related to information structures on the Internet/Web. lys propositionis to to provide the student with the necessary skills, from a theoretical and practical point of view, for the construction of models based on, used for the organization of communication, based on the retrieval of information in a knowledge domain. http://www.filosofiacienciaarte.org/index.php/curso-programacao-python/1068-web-semantica

9 The collaboration of Hélio Santana (Student at the Department of Computer Science) and Aimê Rivero (Student at the Department of Philosophy) stand out.
} 
- Review of relationships.

The Campus ontology was converted into OWL (Web Ontology Language) by Protégé, a free software for ontology editing and which has a framework with an intelligent construction system, in the OWL language. The OWL language was chosen because it has more devices to express meaning than other languages such as: $X M L, R D F$, RDFS. For creation, the Ontology Development 101 methodology was used, in which the following are established:

- Classes;

- Class hierarchy;

- Objects;

- Hierarchy of objects (predicates);

- Properties;

- Class attributes; and

- Instances or individuals;

For the construction of the ontology, it was necessary to identify and register the subjects, predicates and objects (ontology triples) that are related in the Campus workflow. It is understood as subject: the previously registered classes that perform some action; in turn, the predicate is the actions that a subject exerts on an object and, to conclude the relationship, the objects are those that suffer the action. Table 2 exemplifies some of the relationships mapped in the creation of the ontology, in the form of triples.

Table 2 -Ontology Triples

\begin{tabular}{|l|l|l|}
\hline Subject & Predicate & Object \\
\hline Editors & Elaborate & Pre-agenda \\
\hline Editors & Aprove & Subject \\
\hline Editors & Decline & Article \\
\hline Editorial Board & Define & Platform \\
\hline Editorial Board & Discuss & Metrics \\
\hline Editorial Board & Define & Reporter \\
\hline
\end{tabular}




\begin{tabular}{|l|l|l|}
\hline Reporters & Investigate & Agenda Request \\
\hline Reporters & Construct & Article \\
\hline Reporters & Execute & Interviews \\
\hline
\end{tabular}

Source: SILVA, 2019

In Figure 5, Campus Ontology Graph (Source: SILVA, 2019), it is possible to visualize an ontology graph on the right, and the classes on the left in the Protégé software. The figure shows an ontology representation from a graph, where each node of the graph is represented by classes and each line demonstrates the relations or predicates. See APPENDIX 5.

The built ontology has several nodes and branches (links) that can be approximated and better visualized in the program. Elements represented in boxes are classes, directional lines indicate relationships or predicates to other classes. On the left side of the image, we have the representation of some classes and, on the right side, the instances identified by the purple diamonds. When analyzing the graph, we understand that some advantages to creating an ontology are:

- share an information structure between people or software agents;

- Enable the use of the knowledge domain;

- Make the hypotheses about the domain clear;

- Separating domain knowledge and knowledge from operational knowledge;

- Analyze the knowledge domain.

By portraying, in this work, the Campus workflow, we seek to transmit knowledge about the newspaper in a structured way, provide a broader view of the newsroom, facilitate the planning for new groups and to continue research about the newspaper. This proposal was made possible with the validation of the workflow by the Editorial Board, which supported the entire research of this work.

All the work was oriented towards turning the applied knowledge of the Campus a common knowledge, allowing the reuse of the workflow and the transposition of natural language processes to a machine-understandable language and in line with the data structuring of the Semantic Web.

During the construction of the ontology, there were difficulties in describing the decision-making processes and mapping all paths and alternatives, for example, the reasons and possibilities that can cause an agenda to be discontinued. Faced with this adversity, we realized that a possible solution was to continue the work, adapting the 
process modeling, and verifying whether the software could include steps subject to the business context. The decision of discontinuing the agenda or not, would be better resolved if the workflow editing was adaptable by the next Campus teams in a more practical way.

\section{Business Process Management (BPM) in newsrooms}

There is nothing new in saying that Journalism is in crisis but to anounce that ICTS offer opportunity requires further explanation. Journalism is challenged by the growing digitization of processes and the presence of social media, hence it can be said that the reduction in the number of subscribers and the loss of advertisement revenue can be recovered using ICTs, as long as their use or application happens on a well-founded basis and an extremely professional digital transformation, and this is reason to say that ICTs offer opportunities. Research areas, software developers and tool producers can act to support the production of news, facilitating the exploration of the communication market in times of digital economy (BERVEN et al, 2020).

The production of news as a business process makes perfect sense, as we have a set of interconnected activities that are performed in an organizational environment, that is, the coordination of the production of a newspaper newsroom, which every day becomes more supported by more adequate tools and information systems to achieve the objective proposed by management (TEIXEIRA JUNIOR, 2017).

Innovative technologies that are already acting at the service of journalism are: Data Mining, Artificial Intelligence, Machine Learning and Natural Language Processing. In this section, another of these areas ais ddressed: Business Process Management (GPN). It is a well-established research field for Computer Science, Information Systems and Management, with wide use in large corporations.

\subsection{Types of processes}

There are several classifications for business processes according to their characteristics and a multitude of notations or Modeling Languages for operational processes (e.g., BPMN, Petri Nets, BPEL, YAWL, Process Algebra, IDEF, UML and EPC). Models can be mathematical, graphic, physical, narrative, or some combination of these. And notations have in common that processes are described in terms of activities. Thus, one practice is to separate processes in relation to their structures and flows, so it is possible to classify them as (FONSECA et al, 2018):

(i) Strongly framed or structured processes (Fully predictable, highly repetitive); 
(ii) Loosely framed processes: represents the behavior of the process and a set of a priori constraints, so the model describes the standard way of doing things;

(iii) $A d$-hoc framed processes: cannot be determined in terms of explicit process logic during modeling time, due to lack of domain knowledge or complexity of task combinations.

(iv) Totally unframed or unstructured processes: totally unpredictable, highly nonrepeatable, and process participants need to make decisions using their expertise to create on-demand activities.

\subsection{Modeling Languages}

In modeling, process annotations and analysis play a central role in business process management. Therefore, the choice of modeling language to represent an organization's processes is essential. There are some ways to divide or classify languages in the literature (TEIXEIRA JUNIOR, 2017). Here, three classes of languages are presented to facilitate their characterization or identification (FONSECA et al, 2018):

- Formal languages: processes are studied using theoretical (mathematical) models

- Conceptual languages: have rigorous, low-level semantics, and provide an approximate value of desired behavior;

- Execution languages: business processes specified in BPEL are fully executable and portable across BPEL tools.

BPMN is a graphical language which aims to solve business communication through an intuitive notation language, through complex processes, considered the global standard for process modeling by the Object Management Group (OMG) in 2006.

The BPMN Business Process notation standard gives companies the ability to understand their internal business procedures in a graphical notation and gives organizations the ability to communicate these procedures in a standard and clearer way. This allows organizations to quickly adjust to business new circumstances: internal, external and business-to-business - B2B (FONSECA et al, 2018).

\section{3 do Campus BPM Map}

A communication organization is known as having an information flow, which was here modeled as a domain ontology, and it can also be analyzed as a BPM (Business Process Management) map, thus facilitating the achievement of its objectives. (NUNES et al, 2016). BPM Business Process Management has been applied in a large number of 
organizations in recent decades, generally describing a flow of control of well-structured activities. The journalism area would not be an exception: news production can be modeled with the help of BPM techniques and software.

The Experimental Journal of FAC/UnB was modeled in a simple way about 6 (six) years ago (see Figure 6 -APENDIX 6 - First Campus BPM Map Using Bizagi ${ }^{10}$ ). This was the first approach, and it was possible to represent a process as a small set of activities, and a little bit of their behavior. You have a set of a priori constraints so that the process model describes the "standard way of doing things." However, a posteriori, a model requires additions, removals or sequence generation of alternative activities during runtime.

However, it must Be stated that the processes in a journalistic newsroom are predominantly of type ii, iii or iv. In the case of an experimental journal, for this study it is considered as a loosely framed process. See Figure 7 (APPENDIX 7) where it is possible to build a model much closer to the real world. The preparation of the Campus BPM Map was the result of a collaborative work by students ${ }^{11}$ from the discipline Special Topics in Communication 1 - Ontology (online course) at FAC/UnB.

The model was proposed to describe the work process, which comprises the stages of production, presentation, distribution and content analysis. The model represented in Figure 7 was developed in the Heflo ${ }^{12}$., Process Modeling and Management Tool, an online platform, freemium, with intuitive use and vast visual resources. See APPENDIX 7: Figure 7 - Campus BPM map graph (APPENDIX 7) using $\mathrm{HEFLO}^{13}$. Source: Collaborative work of students from the TEC1 Course - Ontology on the Internet (2019.

There is not always a common understanding of the management of a business process for its sponsors (teachers) and participants (students). Therefore, it is normal for them to experience a gap between their perspectives, as happens between the business owners and the vision of the IT support area.

As to the conventional approach to modeling with the preparation of the Campus BPM Map, it was possible to understand the process as an information flow and actions, proposing changes and improvement of activities (workflow) that the organization

\footnotetext{
${ }^{10}$ Bizagi is one of the modeling language. It is made up of a platform consisting of three components. Each component facilitates a fundamental step in transforming and automating processes: http://www.bizagi.com/pt/treinamento

11 Students Aimê Rivero, Hélio Santana and Thallita Silva worked on the construction of a BPM map for the Campus newspaper (2018).

$12 \mathrm{HEFLO}$ is a business process documentation tool in which process flows are edited online and. documents are automatically generated. https://www.heflo.com/pt-br/ferramenta-de-documentacao-de-processos-denegocio

13 HELFO is a Platform for managing businesses: http://hefol.com
} 
(Department of Journalism) can carry out to reach its goals, then it makes sense to develop a more complete or complex approach if one considers it necessary.

In more advanced studies, it is necessary to offer semantic support to the journalist to design processes on demand in a flexible journalistic newsroom ${ }^{14}$.. However, it is known that not all processes described are characterized as having well-structured flows. In real life, there is a constant need to meet unanticipated demands or unwanted events that may arise in the workflow. Unplanned situations can appear at any time during the execution of the process, which leads to the need for remodeling to allow for all paths to be dealt with, and another level is reached, that is, flexible processes (NUNES et al., 2016).

\section{Final Considerations and Perspectives}

The modeling of the news production process of Campus Multiplataforma FAC/UnB journal demonstrates the ability to use mental and conceptual maps to arrive at the ontology of the Campus workflow. The results were achieved and are available for the responsible journalist and his news production team to follow the same path described here if they wish. As advantages, he will be able to understand and improve the steps and/or the entire information flow of how an experimental university newspaper behaves. But first, the context and characteristics of the journal under study must be considered, and the necessary adaptations in the modeling process must be made.

By mapping the Campus workflow, the aim is to transmit knowledge about the newspaper in a structured way, to provide a broader view of the newsroom, and facilitate planning for new groups and continue the research on the newspaper. This proposal was made possible with the validation of the workflow by the Editorial Board of the Campus, a measure that supported the entire research of this work.

\section{Applicability of the experiment in other newsrooms:}

The modeling or elaboration of the workflow does not represent a trivial application of one or more tools, as it is above all, a planning work method. Its use by a professional or a team in the field of journalism requires knowledge of mental and

\footnotetext{
14 This research has been sponsored by Fundação de Apoio à Pesquisa do Distrito Federal (FAP-DF), under the project "Flexible organizational information systems based on business processes with contextual semantic guidelines." Grant Number SEI 00193-00000096/2019-78. This case study of the project is part of the Experimental Laboratory for the Study of Digital Languages for Mobile Devices (Labdim) of the Department of Communication, University of Brasília, registered under number 485707 at CNPq / 2013-6, in partnership with the Department of Computer Science (UnB) and Brunel University London, UK
} 
conceptual maps and ontologies. Thus, the most recommended path is the composition of an interdisciplinary group were journalists and computer science professionals with experience in Semantic Web work together. The help of a professional with knowledge of ontologies, or the training of journalists in the subject, enables the development and the capacity to abstract, from the mental model, the productive process of news and information. A second modeling path is recommended, which is the preparation of the BPM (Business Process Management) Map.

The modeling or elaboration of the workflow does not represent a trivial application of one or more tools, as it is, above all, a planning work method. Its use by a professional or a team in the field of journalism requires knowledge of mental and conceptual maps and ontologies. Thus, the most recommended path is the composition of an interdisciplinary group where journalism and computer science professionals with experience in Semantic Web work together. The help of a professional with knowledge of ontologies, or the training of journalists, enables the development and the capacity to abstract, from the mental model, the productive process of news and information. A second modeling path is recommended, which is the preparation of the BPM (Business Process Management) Map.

When carrying out the study, following the line drawn from the construction of models, here starting with a mental map, then a conceptual map, a domain ontology was achieved. The methodology (Design Science Research - DSR) adopted by the students, researchers and professors involved was the benchmark that best served and should meet other applications. All the work was oriented towards making common knowledge applied to the Campus Multiplataforma, and allowing the reutikization of the workflow in similar situations or considering due adaptation. In the case at hand, it started with the transposition of natural language processes to a machine-understandable language and in tune with the data structuring of the Semantic Web. Other paths can be adopted, depending on the situation found byt the interdisciplinary group.

During the construction of the ontology, we verified the difficulty in describing the decision-making processes and mapping the reasons that can make an agenda be disconsidered or not, for example. In this sense, the construction of the BPM Map (business process modeling) was complemented with a second model. Soon, two portraits were obtained for the Campus workflow. It should also be noted that this is the result of more than 4 years of cooperative and collaborative work between the departments of Journalism and Computer Science at UnB, and in this research it was a decision-making assertion. 


\section{Perspectives:}

The context of digital transformations is also growing in organizations and communication companies. Business management models, which have many conceptual names such as digital journalism, data journalism and cyber journalism, will continue to grow in the economic and technological ecosystem. Thus, the field of Communication seems to be a significant theme for academics and professionals when they deal with their research objects, concerns and problems within the context of the contemporary information ecosystem (DOS SANTOS, 2021).

Virtual newsrooms have their perspectives assured in the third decade of this century, operating in a distributed manner, and will continue to guide their processes by reviewing the production information flow, and having data journalism as a process to be followed. These same contemporary newsrooms has adapted to new ways of operating and producing content. The processes are strengthened with the use of ICTs, from checking to face fake news, that is, better collection, good filtering, the use of construction and content presentation tools, to distribution in reliable channels. Always being alert to the need to measure the impacts and the value of news, then the engagement in hybrid environments, entering the experimental and convergent world of social media (ISHIKAWA et al, 2021).

The prospects of continuing tensions between prioritizing and balancing reader's preferences and journalists' control of news in the workflow are real and useful. What is certain is that it becomes a struggle between the new way of producing journalistic stories mediated by ICT, and the legacy of today's practices in centralized newsrooms. This has as an adverse scenario the indicators of the advertising market and the survival of journalism (TSAKARRESTOU; POGKAS, 2017).

\section{Referências}

ALMEIDA, M; BAX, M. Uma visão geral sobre ontologias: pesquisa sobre definições, tipos, aplicações, métodos de avaliação e de construção. Revista Ciência da Informação. 32(3), 2003.

BARCELLOS, Zanei Ramos; GIL, Patrícia Guimarães. A Forma Flexível e Inclusiva de Fazer Jornalismo da Geração Z. Cadernos da Escola de Comunicação, v. 16, n. 1, p. 26-42, 2018.

BARCELLOS, Zanei; SILVA, Thallita Alves. Mapeamento do workflow do processo de produção de notícias multimídias para jornal digital Campus Multiplataforma. 2020. Disponível em:http://www.intercom.org.br/sis/eventos/2020/resumos/R15-05331.pdf Acesso em: 21 mar. 2021.

BERNERS-LEE; T.; HENDLER, J.; LASSILA, O. The Semantic Web. A new form of Web content that is meaningful to computers will unleash a revolution of new possibilities. 2001. 
BERVEN, A.; CHRISTENSEN, O. A.; MOLDEKLEV, S., OPDAHL, A. L.; VILLANGER, K. J. A knowledge-graph platform for newsrooms. Computers in Industry, 123, 103321. 2020

BREITMAN, K. Web Semântica: a Internet do Futuro. Rio de Janeiro: Editora Eletrônica, 2005.

BUZAN, Tony. Mapa Mental. 2016.

DEUZE, M.; WITSCHGE, T. (2018). Beyond journalism: Theorizing the transformation of journalism. Journalism, 19(2), 165-181. 2018.

DE SOUSA, C. A. X.; BARCELLOS, Z. R. Aplicativos Jornalísticos | Universidade de Brasília, Brasília, DF. 2019. Intercom - Sociedade Brasileira de Estudos Interdisciplinares da Comunicação XXI Congresso de Ciências da Comunicação na Região Centro-Oeste - Goiânia - GO - 22 a 24/05/2019. Disponível em: https://portalintercom.org.br/anais/centrooeste2019/resumos/R66-0440-1.pdf

DOS SANTOS, M. C. Big Data and the Studies of Communication in Brazil -Notes on reconfiguring a knowledge field In: MEDEIROS NETO; LEAL; GHINEA (org). Digital Convergence in Contemporary Newsroom: Media Innovation, Content Adaptation, Device Mobility, and Cyber Journalism. Cidade: Editora: Springer, Berlin, Heidelberg. 2021.

FONSECA, M. B.; ISHIKAWA, E.; MEDEIROS NETO, B.; VICTORINO, M. Ferramenta para Anotação Semântica de Processos de Negócios de uma Redação Jornalística. ONTOBRÁS 2018, SP, p.239-244 http://ceur-ws.org/Vol-2228/.

ISHIKAWA, E; MEDEIROS NETO, B. Newsroom 3.1: Incorporations Social Media Management in Semantic Newsrooms with Flexible Business Process. In VIII Seminário Hispano-Brasileiro de Pesquisa em Informação, Documentação e Sociedade 2019. Escola do Futuro ECAIUSP - São Paulo - 11 à 14 de Novembro de 2019.

ISHIKAWA, E.; MEDEIROS NETO, B.; GHINEA, G. Perspectives of the Journalists Content Production from print newspaper to Virtual Newsroom 4.0 In: MEDEIROS NETO; LEAL; GHINEA (org). Digital Convergence in Contemporary Newsroom: Media Innovation, Content Adaptation, Device Mobility, and Cyber Journalism. Cidade: Editora: Springer, Berlin, Heidelberg. 2021.

JORGE, T. M.; MEDEIROS NETO, B. Journalistic Newsrooms: convergence and innovation on three continents. A case study on five media organizations. In: MEDEIROS NETO; LEAL; GHINEA (org). Digital Convergence in Contemporary Newsroom: Media Innovation, Content Adaptation, Device Mobility, and Cyber Journalism. Cidade: Editora: Springer (no prelo), Berlin, Heidelberg. 2021.

LAMMEL, Iuri; MIELNICZUK, Luciana. Aplicação da Web Semântica no jornalismo. Estudos Em Jornalismo e Mídia, v. 9, n. 1, p. 180-195, 2012.

MOLINA, Fernando; MEDEIROS NETO, Benedito. O perfil do jornalista 3.0: Novas competências necessárias para o jornalismo no século XXI. In Simpósio Internacional de Educação e Comunicação-SIMEDUC, n. 8, 2017.

NETO, B. M.; ISHIKAWA, E.; GHINEA, G., \& GRøNILO, T. M. (2019, January). Newsroom 3.0: Managing Technological and Media Convergence in Contemporary Newsrooms. In Proceedings of the 52nd Hawaii International Conference on System Sciences. 2019.

NUNES V.T., SANTORO F.M., WERNER C.M.L., RALHA C.G. (2016) Context and Planning for Dynamic Adaptation in PAIS. In: Reichert M., Reijers H. (eds) Business Process Management Workshops. BPM 2016. Lecture Notes in Business Information Processing, vol 256. Springer, Cham. https://doi.org/10.1007/978

SANTOS, É., MEDEIROS NETO, B., LENZI, A., \& Ghinea, G. Redações jornalísticas em contexto de convergência: um estudo comparativo exploratório no Brasil, na Costa Rica e na Inglaterra. Comunicação \& Inovação, 20(43). 2019. 
SILVA, T. A. Workflow para auxiliar na modelagem de processos de produção de notícia em jornal laboratório. TCC apresentado à Faculdade de Comunicação da Universidade de Brasília, Brasília, DF. 2019.

TEIXEIRA JUNIOR, Gilmar et al. Modelagem de sistemas de informação para a mineração de processos: características e propriedades das linguagens. Universidade Federal de Goiás. 2017.

TRONCY, Raphaël. Bringing the IPTC news architecture into the semantic web. In: International Semantic Web Conference. Springer, Berlin, Heidelberg, 2008. p. 483-498.

TSAKARRESTOU, Betty; POGKAS, Demetrios. Data led newsrooms: Integration, collaboration and workflows in data first!media organizations. In For Future of Media and Communication Research: Media Ecology and Big Data International Conference N Fudan University, Shanghai, China. November, 2017.

\section{APENDICES - Big Figures}

APPENDIX 1: Figure 1 - The Semantic-web-stack

Fonte: Wikipédia - https://en.wikipedia.org/wiki/File:Semantic-web-stack.png.

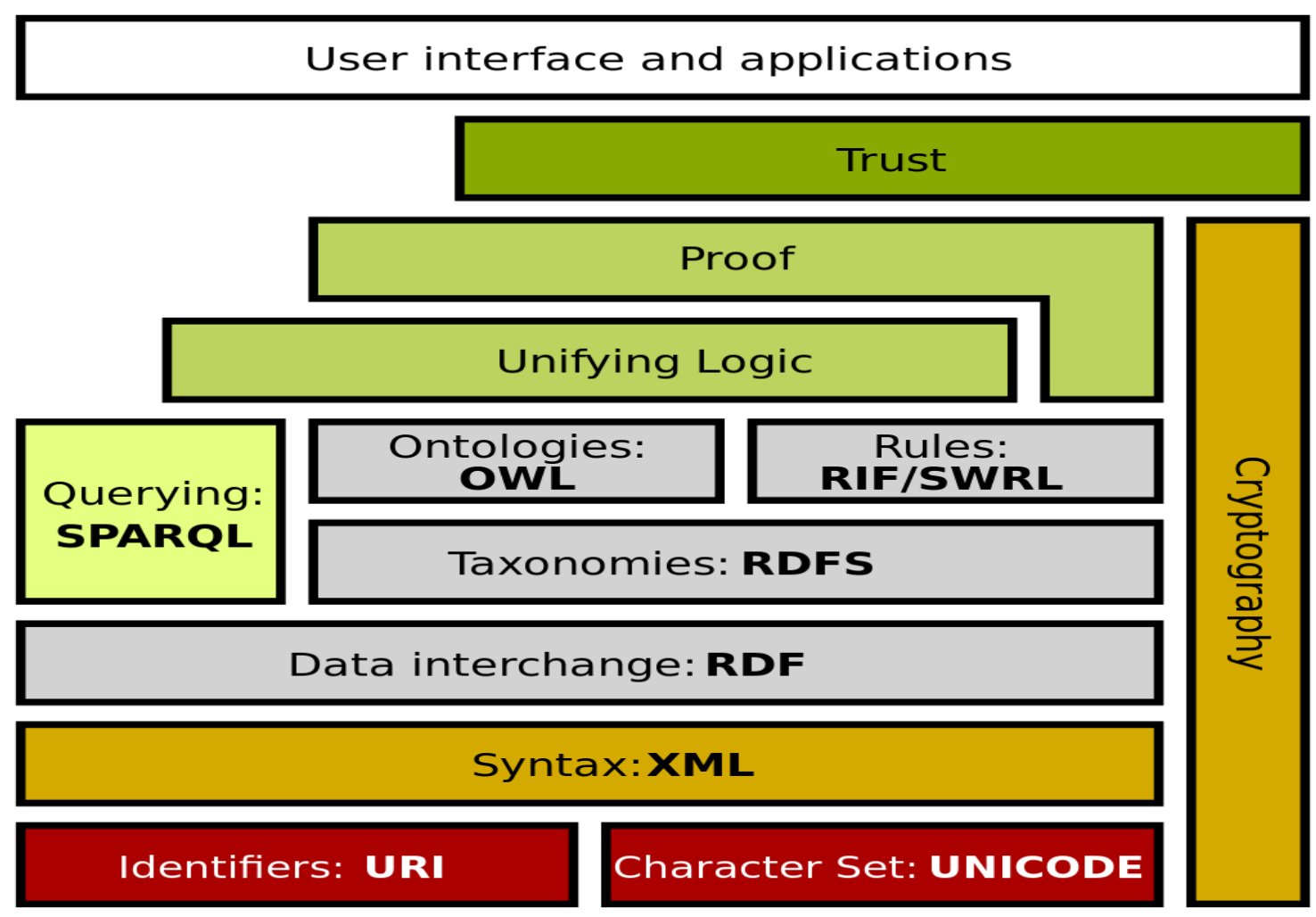


APPENDIX 2: Figure 2 - Composition of the Editorial Board 1/2019 (Conceptual Map) Source: SILVA, 2019, p.59

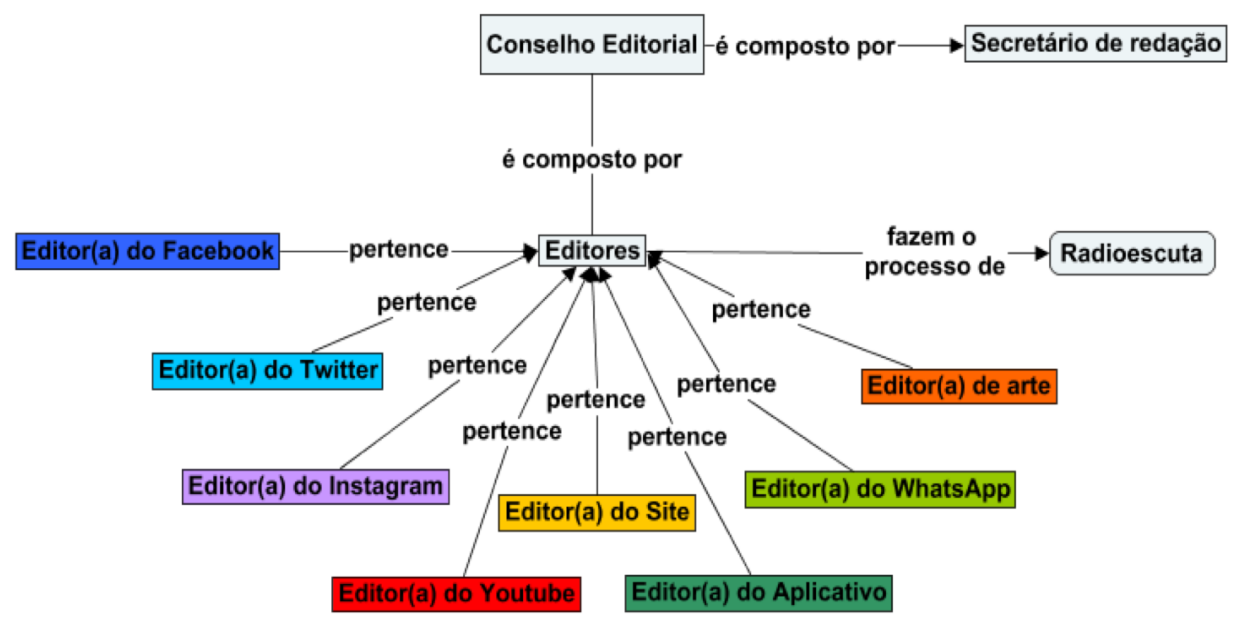


APPENDIX 3: Figure 3 - Mind map in chronological view. Source: SILVA, 2019.

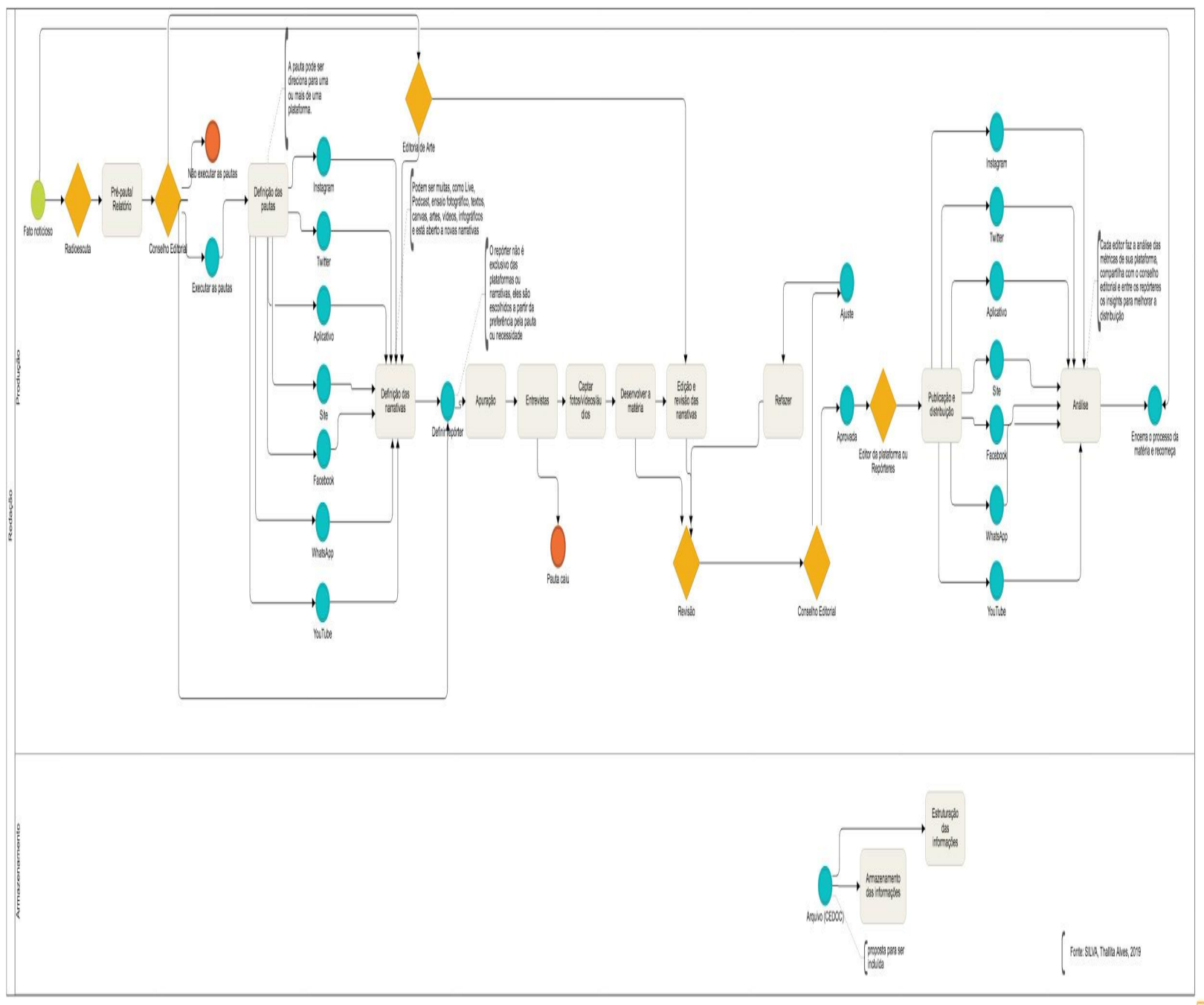


APPENDIX 4: Figure 4 - Conceptual Map of the Multiplatform Campus.

Source: SILVA, 2019 , p.73.

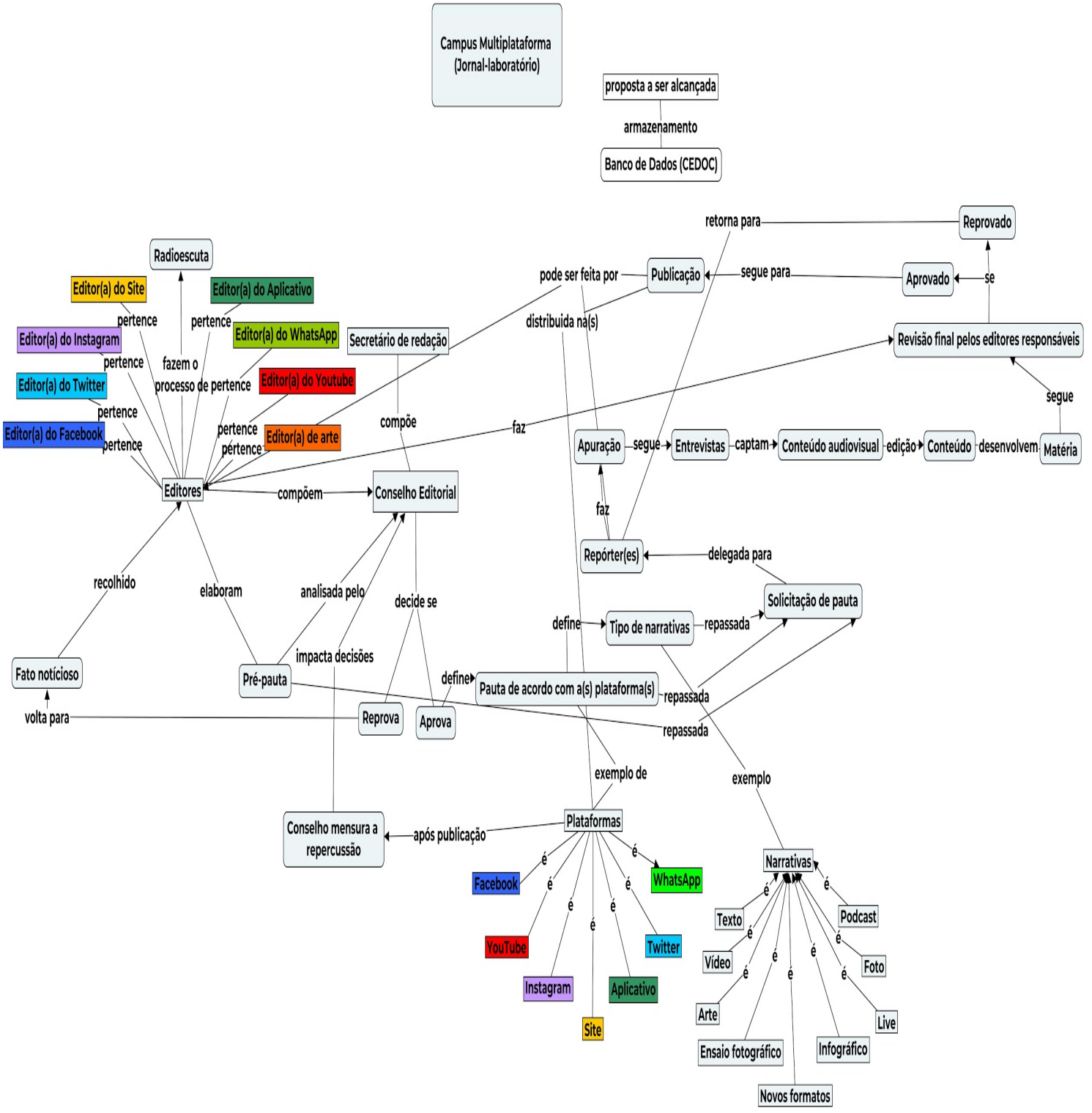


APPENDIX 5: Figure 5 - Campus Ontology Graph. Source: SILVA, 2019

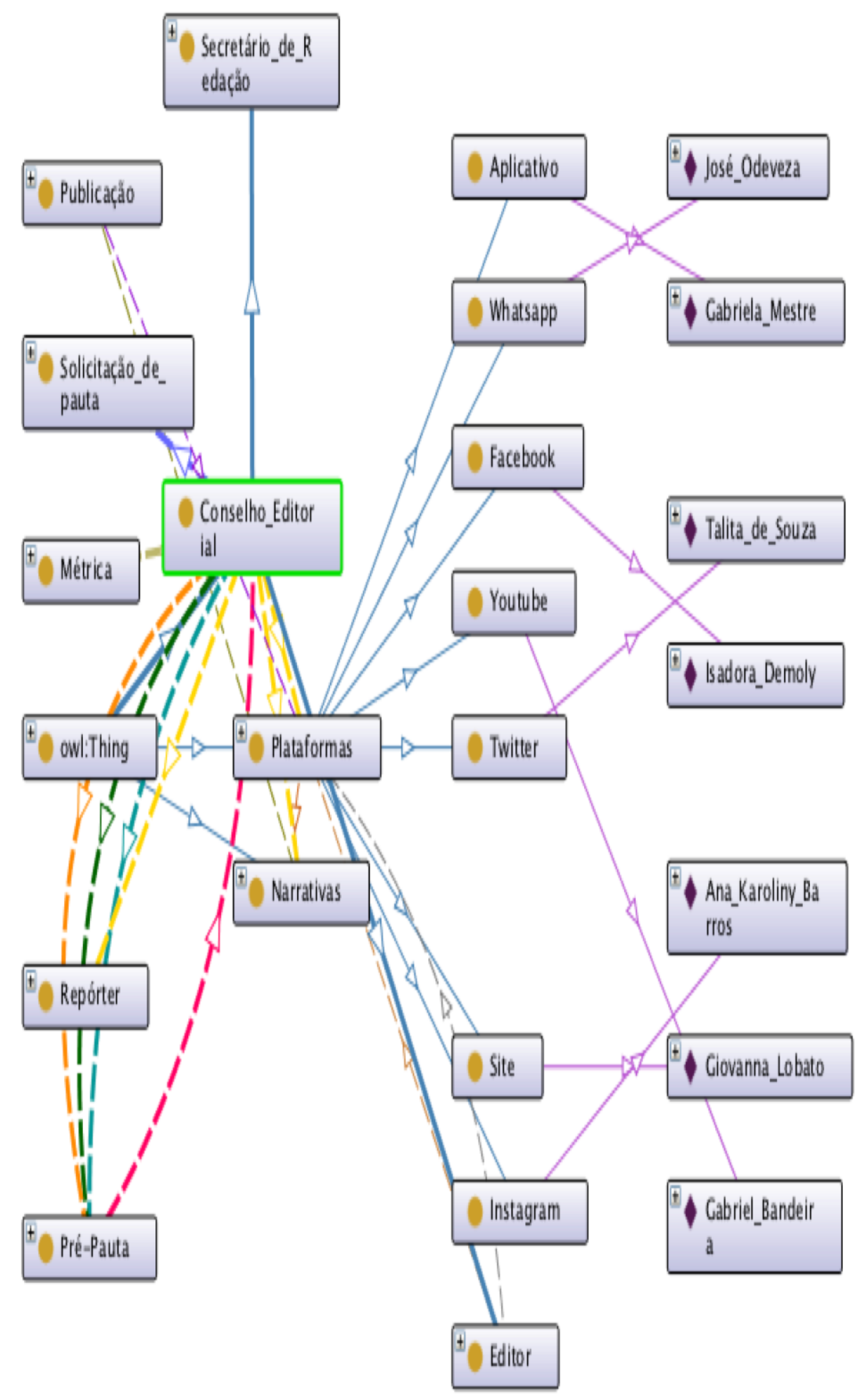


APPENDIX 6: Figure 6 - First Campus BPM Map Using Bizagi ${ }^{15}$

Source: Collaborative work by students of Journalism in Digital Environments/FAC/UnB (2016)

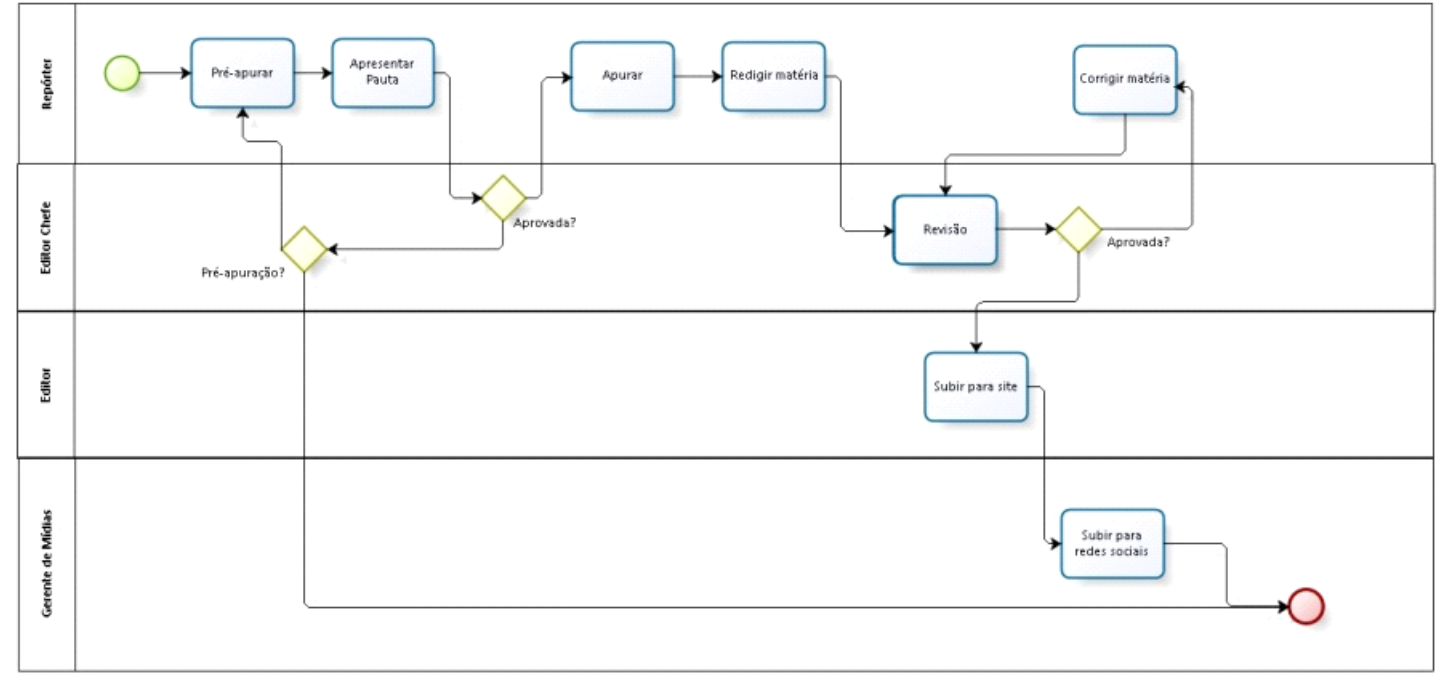

${ }^{15}$ Bizagi is one of the modeling language. It is made up of a platform consisting of three components. Each component facilitates a fundamental step in transforming and automating processes: http://www.bizagi.com/pt/treinamento 
APPENDIX 7: Figure 7 - Graph of the Campus BPM map (APPENDIX 7) using HEFLO. Source: Collaborative work of students from the TEC1 Course - Ontology on the Internet (2019).

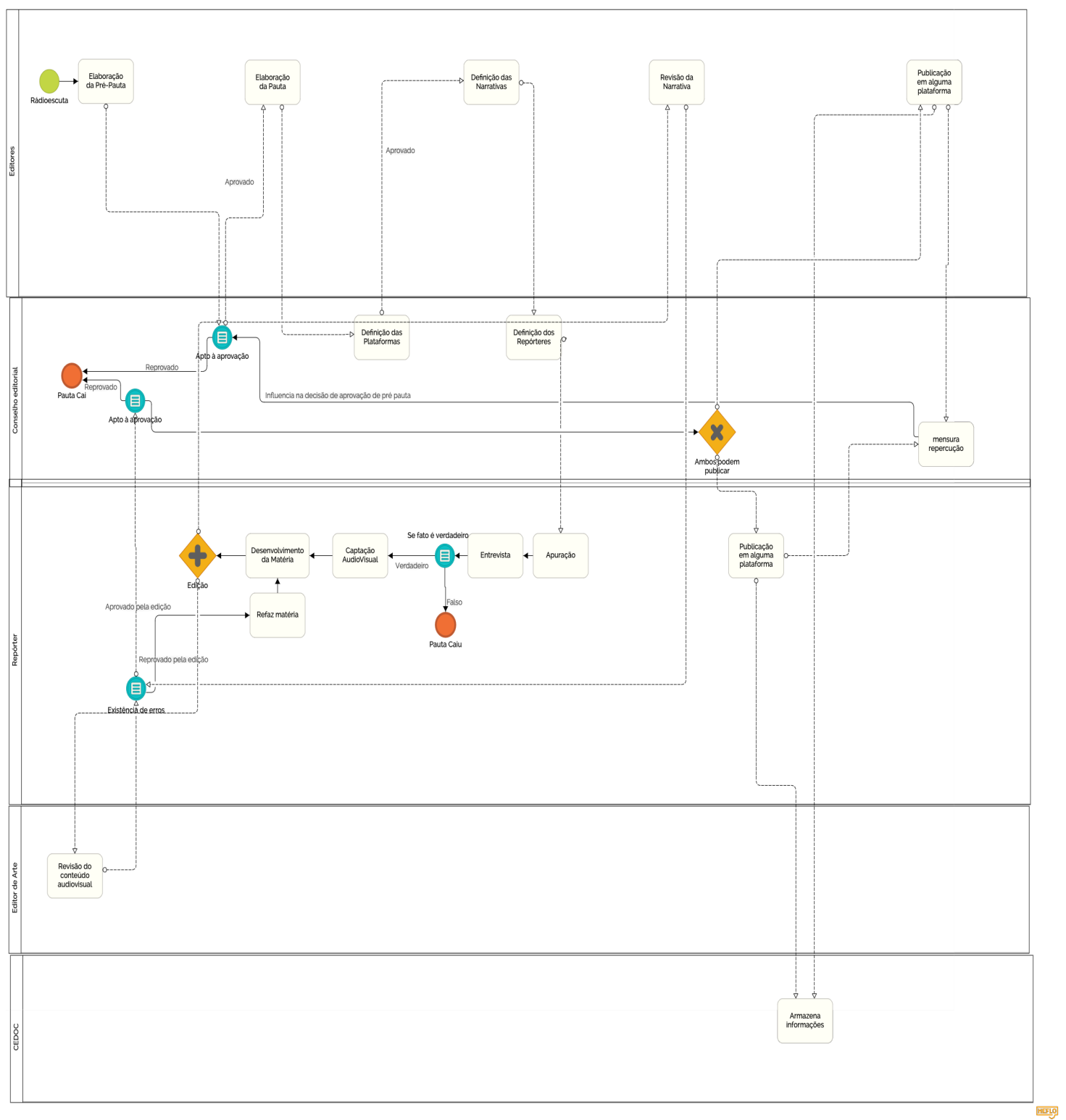




\section{Crevisto \\ Observatório}

RESUMO:

Esta pesquisa mostra modelagem do workflow de um jornal universitário com base em mapas mentais e conceituais e propõe uma ontologia de domínio. O estudo foi realizado com base em conceitos, como jornalismo multiplataforma, web jornalismo e uso de TIC. Em termos metodológicos, trata-se de um estudo de caso, combinado com observação de participantes por meio de entrevistas semiestruturadas. Como parte da modelagem, elaborou-se um mapa mental do fluxo de trabalho do Campus. Depois o

\section{RESUMEN:}

Esta investigación muestra modelar el flujo de trabajo de un periódico universitario a partir de mapas mentales y conceptuales y propone una ontología de dominio. El estudio se realizó a partir de conceptos como periodismo multiplataforma, periodismo web y uso de las TIC. En términos metodológicos, se trata de un estudio de caso, combinado con la observación participante a través de entrevistas semiestructuradas. Como parte del modelado, se desarrolló un mapa mental del flujo de trabajo del Campus. Luego se mejoró el proceso a un mapa conceptual y finalmente se llegó a una ontología. Los resultados muestran la posibilidad de comprender visualmente el proceso de un periódico, compartirlo o extrapolarlo y aplicarlo a otras redacciones, y también mejorar el flujo de trabajo con el apoyo del mapa de gestión de procesos (BPM).

PALABRAS-CLAVES: flujo de trabajo; periodismo multiplataforma; periódico experimental; mapa mental y conceptual; ontología.. processo foi aprimorado para um mapa conceitual e por último chegou-se a uma ontologia. Os resultados mostram a possibilidade de se compreender o processo de um jornal de forma visual, compartilhá-lo ou extrapolá-lo e aplicá-lo em outras redações, e, ainda, aprimorar o fluxo de trabalho com apoio do mapa de gestão de processos (BPM).

PALAVRAS-CHAVES: workflow; jornalismo multiplataforma; jornal-experimental; mapa mental e conceitual; ontologia. 